\title{
THE SYMBOLISM OF HOPE IN THE LYRICS OF A NEW DAY HAS COME AND I'M ALIVE IN CELINE DION'S ALBUM A NEW DAY HAS COME
}

\author{
Trifena M. Rumambi
}

\begin{abstract}
The purpose of this study is to identify thesymbols of hope in Celine Dion's songs A New Day Has Come and I'm Alive in the Album A New Day Has Come. Descriptive qualitative design is used in this research. The data were collected by listing the lyrics per stanza and line of Celine Dion's two chosen songs that being suitable with the main purpose of this research. The analysis of the data oriented on the objective approach according to M. H. Abrams. The findings show that the symbols of hope were strongly presented in two chosen songs. The presentation of hope was dominated by symbols in the form of figurative language which are metaphor and personification. Those symbols were revealed hope thatencouraged listener for never give up hoping and keep motivated to face daily life. Furthermore, it is expected that this study will be useful for the further researchers that about to conduct the study related and helpful for the readers to study poetry in song, especially in essence.
\end{abstract}

Keywords : Symbolism of Hope, Lyrics, Celine Dion, Song

\section{INTRODUCTION}

Hope is what one craves, an optimistic state of mind that is based on an expectation of positive outcomes with respect to events and circumstances in one's life. As (Strickland 2015:9) stated Hope is the feeling that what is wanted can be had or that events will turn out for the best or the act of looking forward to something with desire and reasonable confidence or feeling that something desired may happen. It reflects what one finds in a literary work including a song. Song is a part of literary work. Literature is a kind of essay based on experience or imagination. Maru (2014:4) argues that a literary text is fiction, it provides real world experiences, whereas it reveals the connection that happened in society where the target language is spoken.
In this research. song will be used, it a song with wide appeal, that is typically distributed to large audiences through the music industry. Popular song is a kind of music that is currently favored by ordinary people. It is a kind of music that most people loved.

In relation to literature, song, song's lyric, and poetry are also related as a part of literature, because poetry can be translated into musical lyrics as a song.

A meaning may be found in symbols that related with imagery figurative language. Anything that signifies something else at the range of reference beyond itself is known as symbols (Abrams:1971). In other side, Groys Kerraft,said that figurative language or style is a way of showing mind through a special language that 
shows the soul and the characteristic of the writer (language user). Figurative language that commonly used is personification, metaphor and simile (2009:113).The symbols that have a message is a strong foundation to reveal the presentation of hope that being conveyed in imagery figurative language in the song lyrics. Symbols and images are figures of speech that enhance a work of art even though in an indirect manner. The use of imagery and symbolism enriches the subject matter of art by translating meaning through associations and by establishing contrast and comparisons through what Caroline Spurgeon terms, "likeness between dissimilar things. In other hand, the necessity of authentic media to enhance student's vocabulary mastery, song recently has widely used as tool of achieving some purposive vocabularies in material that contains authentic language, which is easily obtain, provide vocabulary, grammar and cultural aspects and are fun for the students.

In this research, the writer is interested in investigating the symbols in lyrics of Celine Dion's songs because songs are the daily need for many people in modern life and can attract people to learn English. In this research there are two songs of greatest hits of Celine Dion that will be taken namely A New Day Has Come and I'm Alive.

\section{REVIEW OF LITERATURE}

Song as part of literature has been broaden the insights in Literature, since it is obtainable, enjoyable, fun and is inevitable in human life, especially as students, it could be viewed as means of delivering and describing life situation even to reduce stress, show feeling and etc. Apart from it, English as a foreign language that taught in school lately uses song in the material which integrated with curriculum 2013. It proves that the existence of song as the means of teaching and improving ESL student's language mastery has broadly admitted by institution of education for some reasons and purposes eventually. One of the most obtainable in learning English through song is vocabulary.

Song as part of literature has been broaden the insights in Literature, since it is obtainable, enjoyable, fun and is inevitable in human life, especially as students, it could be viewed as means of delivering and describing life situation even to reduce stress, show feeling and etc. Apart from it, English as a foreign language that taught in school lately uses song in the material which integrated with curriculum 2013. It proves that the existence of song as the means of teaching and improving ESL student's language mastery has broadly admitted by institution of education for some reasons and purposes eventually. One of the most obtainable in learning English through song is vocabulary. Maru (2009:1) stated "Having an active EFL (English as a Foreign Language) class has been a dream for almost all of teachers". Therefore, song can hold a big role in improving, enriching student's vocabulary and sharpening student's sensitivity of language use because it can stimulate students to learn actively without feeling under pressure. It has been known broadly that vocabulary is fundamental to foreign language 
teaching because without vocabulary enough, students cannot not only express their own ideas but also comprehend others. This is how Wilkins (1972: 111112) summed up the importance of vocabulary learning : "without grammar very little can be conveyed, without vocabulary nothing can be conveyed." Song has lyrics that own a lot of vocabulary about noun, verb and etc. Surely, we may broaden students' insights in literature and also to enhance student's English vocabulary.

\section{Symbolism}

Symbolism is a system of symbols or representations. It is the art or practice of using symbols especially by investing things with a symbolic meaning or by expressing the invisible or sensuous representations.

An example of a symbol in poetry occurs in the King James translation of Psalm 23, quoted on page 160. The poem begins with a metaphor: God is like a shepherd and I (the speaker) am like one of his sheep; just as a shepherd takes care of his sheep, so will God take care of me. (Griffith 2011) According to M H. Abrams (1971):

Anything which signifies something else; in this sense all words is symbols

As commonly used in discussing literature, however, symbol is applied only

To a word or set of words that signifies an object or event which itself

Signifies something else; that is the words refer to something which suggests

A range of reference beyond itself. (168)
Further, according to Kennedy, symbol is a thing in literary work which have more than literal meaning, he pointed thing does not provide one meaning only (Kennedy 206). Tyson also states that, sometimes symbols has private meaning and only the author of it knows its meaning, and our analysis about symbol within the text can be different from the aouthor's intention, but it does not matter as long our analysis about symbol supports in finding the theme of literary work of our study (Tyson 142).

\section{Figurative Language}

Figurative language is the conscious departure from normal or conventional ways of saying things. This could mean merely a rearrangement of the normal word order of a sentence, such as "Sir Gawain the dragon slew" or "With this ring I thee wed." Such unusual re-arrangements are called "rhetorical" figures of speech"'. (Griffith 2011:132)

Simile is a second category of figurative language: tropes. Tropes (literally, "turns") extend the meaning of words beyond their literal meaning. A simile uses like or as to mark similarities; for example, "Her tears were like falling rain." The following stanza from Shakespeare's "Fair Is My Love" contains several similes (indicated by the underlinings) :

A metaphor also claims similarities between things that are essentially unlike, but it eliminates the comparative words (such as like) and thus equates the compared items. For example, "My heart was a tornado of passion" (not "My heart was like a tornado of passion"). The poem "Love Is 
a Sickness" by Samuel Daniel contains three metaphors - love is a sickness, love is a plant, love is a tempest - indicated here by the underlinings :

Personification analogies can be directly stated or implied. The similes and metaphors in the poems by Shakespeare and Daniel are directly stated analogies; but when Daniel in the last lines of each stanza says that love "sighs," he implies a kind of analogy, personifi-cation; he pretends that love has the attributes of a person.Personification means using comparative similes and metaphors to give living qualities to non-living objects or ideas. It is a part of figurative language. In his Dictionary ofLiterary Terms and Literary Theory, Cuddon states that this figure is "inherent in many languages through the use of gender" (661). A writer can either say something literally, orfiguratively.

\section{Research Design}

Based on this research focus is to analyze the themes in Celine Dion's selected songs, and the qualitative research was used.

Bogdan and Biklen (1992:30)

"Qualitative research is descriptive. The data collected are in the form of words or pictures rather than numbers. The written result of the research contains quotation from data to illustrate and substantiate the presentation." The data will be collected by the form of words, sentences, and video.

In analyzing the data in this research, the writer used objective approach. According to M. H. Abrams objective approach is :
"The objective orientation which on the principle regards the works of art in isolation from all the external part of references, analyze it as a self sufficient entity constituted by its part in their external relation, and sets out to judge its sorely by criteria intrinsic to its mode of being. (1979:26)

\section{RESULTS}

\section{A. Symbols of Hope in A New Day Has Come Lyrics Symbols in the Form of Metaphor}

Claiming the similarities between things that are essentially unlike, but eliminates the comparative words (such as like) and thus equates the compared items recognized as metaphor.

Hope can appear in so many occasion, depends on what or who that made someone get the strength and joy which encouragehis/herwanted to live and believe in positivity of life. The following quotes reflected the hope that caused by the loved ones can change the whole life of someone that also change their positively opinion.

Religious signs were clearly used in this song. A light for example, it is metaphoric expression that representing one of God's character as the saviour that bring out hope. In Hinduism, the scripture symbolized light as inner awakening of hope. Meanwhile, angel viewed as messanger of hope from God and new sun is hope of something new has born.

"Hush now I see a light in the sky

Oh it's almost blinding me

I can't believe I've been touch by an angel with love" (Stanza 4)

Symbol of hope that presenting by word "light" apparently originated 
from religious sign. As in Christian believer commonly used the word light to describe God as the saviour that bring out hope. In Hinduism, the scripture symbolized light as Usha, who is the sister of sun that brings hope. Spritually she symbolizes the inner awakening. In the song, the writer would like to tell that Celine has found a new hope that just awakened inside her soul. Therefore, it is concluded that the word "light" clearly explains that a hope of something that had been waiting for so long and something good has come.

Meanwhile the word "angel" describes the one who brings a warm love and caring at that time. It was actually refers to the baby in the womb that brings joy and happiness. As a Christian believer, Angel was viewed as a sign of "good news"or "helper". Here, the "angel" described as a baby that carrying a good news and helped the family to get lifeagain after the despair of waiting for so long in the middle of impossibility of having a baby after the marriage. The "angel" who is the baby then comes as family's first biggest hope that they have been waiting for.

Those symbols revealed the hope presented as an optimistic feeling and positive energy that encouraged human to act positively and optimistically in facing life trials especially when human have wishes that they want in life.

The symbols of hope in this song also have messages that tell about the determination of the struggle of life of Celine Dion. The hardship she endured she wanted to have a baby desperately, and the great joy she experienced with the birth of her son. Therefore Celine
Dion revealed that this song represents the birth of her child. This song can be used for everyone out there, and the reason to started a new life. This song proves that there will be nothing we will get without effort and hard work, during the marriage life of Celine, she has never had a child, but she has a conviction in her heart, and she declared it through effort, never giving up on the situation, the struggles are too much to keep survive against life. After all,in the end God gave a miracle to Celine, her effort and prayer were answered by the presence of a baby boy.

"Hush now I see a light in the sky

Oh it's almost blinding me

I can't believe I've been touch by an angel with love"

(Stanza 4)

In stanza 4 line 3, the bold expression is a metaphoric expression that representing the feeling of joy right after being touched by the loved one that claim to have the form of an angel which obviously representing a little baby that has been waiting for and brought happiness. As the metaphor tries to compare the attribute of one thing and something else, the author here clearly maintain to express her imagination of the birth of baby that was like the presence of an angel which is marvelous and wonderful, since it was seemed too impossible to happen (in this case to have a baby) of course it was such an unbelievable moments that been waiting for long to happen somehow expecting for the presence of an angel. There by, 
the presence of the baby viewed as the presence of an angel that desperately desired by the author, so that she felt extremely happy when she finally have a baby then she pictured the baby as an angel. Another metaphorical expression that also shows the presence of a baby were presented in the following lines :

"Let the rain come down and wash away my tears

Let it fill my soul and drown my fears

\section{Let it shatter the walls}

\section{for a new sun}

A new day has come" (Stanza 5)

The bold expression above that uses "walls" describing the gloomy past and doubt of having a new born baby that represented as "new sun".The word "new sun" is a symbolic description of a new hope. The quotes "Let it shatter the walls for a new sun"have a strong message of hope that the author would like to express. It implies the positive energy of the sun that brings warm and peace would be able to shatter or to throw away the feeling of sadness that the author suffering from. That was obviously the author's hope that the good news that is the baby would be the one that save them from the despair and to gain hope once again. It carries strong message of hope and courage to face the new challenge that she has been waiting for the rest of her life. It was clearly presented the presence of a baby that just broke all her frustration that feeling and doubt in the past. Therefore, it is expressing the freedom from sadness and beginning of the new hope.

\section{Symbols in the Form of Personification}

The symbols of hope is clearly conveyed in this song by using personification figurative language. The hope in the fifth stanza is how big our problem is, meet and live it, and let it flow like water, as the poet wants to convey Celine's feeling through her problem.

Let the rain come down and wash away my tears Let it fill my soul and drown my fears

Let it shatter the walls for a new sun

A new day has come

(Stanza 5)

The words in line 1 "Let the rain come down and wash away my tears"telling the listener that we shall let"the rain" that symbolizes a problem to be conquered by us. This is conveyed by using personification whereas the author pretends that "the rain" has the attributes of a person that causing a problem to appear. He continues by saying "Let it fill my soul and drown my fears" which implies that the author viewed "the rain" that switched by "it" in the second array as a personthat may destroy the happiness, however the author implied that the life shall be stronger and fearless when the problem comes.

The following quotes is also clearly implied a hope in facing life trials. The author once again uses personification in the third array "Let it shatter the walls for a new sun". He pretends that "the rain" have the attributes of a person that he letto cause 
a problem but in end he believes that there would be another good thing forward after the trialsthat means the author just going to flow like a river that's why he continues by saying "Shatter the wall for a new sun"whereas the new sun symbolizes as a new hope that been waiting for so long.

Through this song, people can see and feel the struggles of one of the big star in the world through her song "A New Day Has Come" that tells to us that life still must we live no matter how bad things are, we must meet and face it. And by those symbols that delivered in the song, the listener may experience the strong force of hope as found in each stanza.

Message of hope in the first stanza is in this world where every people have their own dreams and hopes to be a better person, because everyday is a new day, a new life and a new chapter that we must live.

Message of hope in the second stanza is this life is a secret, everyday, everytime and everywhere, life is a mystery, there is no one people can see our future, and we must to live it. How long we are waiting for something, we are still waiting patiently, because there are many people around us that will always strengthen, and help us.

Message of hope in the third stanza is even though all people have their own life because every human being is different, and definitely there will be problems, and obstacles, and we have to face it even it's difficult. Actually the hard times and the happy times in our life, we must have a conviction in our heart that we can go on and face it.

Message of hope in the fourth stanza is we never know when we will have a complete or a perfect life, or when God will give us a miracle or everything we want whatever it is. But if we are waiting patiently and always have a hope in God, and effort, it's definitely we will get everything that we want and we need. Because the happiness of life that we will get, it will be comparable with our tears, as the light will blind us as the lyrics of the song.

\section{B. Symbols of Hope in I'm Alive Lyrics Symbols in the Form of Metaphor}

Claiming the similarities between things that are essentially unlike, but eliminates the comparative words (such as like) and thus equates the compared items recognized as metaphor.

Courage and optimist feeling of human, is the greatest force one might have to go on living. That force is the form of rising hope. Here, the author used metaphor symbols to describe the power of hope that can bring back the courage and spirit into someone's life. This can also make someone feel extremely excited to go on living.

"I get wings to fly, Oh, I'm alive" (Stanza 1)

"You've set my heart on fire

Filled me with love"

Made me a woman on clouds above" (Stanza 4)

The word "wings" in stanza 1

line 1 describes the hope of the opportunity in starting the life she lives. Over centuries, human recognized wings 
as a tool to fly that only poses by every kinds of birds. In symbolism, wings viewed as courage to rise someone above even beyond to reach the top, somehow a bird fly to reach the sky.

The bold expression clearly showing hope and courage to continue the career life of the author.Meanwhile, "fly" representing optimistic view of life career and track records in life that could be booming and grow better than before. It such she was confidently encouraged to get higher position of her life somehow she wanted to fly with her own wings.

It tells people the positivity about things that may bring great change in achieving life goals. It was strongly emphasized by the word following the wings which is "fly", that suggest the listener that she gets opportunity that she believes can change her life greater than before. The possibility of fly using "wings" and rising up to heaven is believed to be beyond human reach since it is associated with spiritual life that aims for enlightenment which believed by some religions like Christian, Hindus, even Egyptian myth. The spiritual life in this song seems implies a strong faith towards achieving a hope, in terms of the authors background, the goal was such as a hope of a bright career will burst and raise the popularity.

The following diction in stanza 4 line 1 clearly associated the strong motivation that awakened from the inside. The word "fire" representing a spirit from the inside to start the new life. Spirit and determination were symbolized as "fire". It seen as an inner light that burns in every human's soul.
That simply representing a strong will of someone that believes optimistically in their heart lies a power that drives them towards all of their desires which then makes them so eagerly chasing after their dreams and hopes.

It was also emphasized by the following diction in line 3 which is "clouds" above whereas it representing the feeling of being superior which showing the position of the important people. It was definitely joyful to feel such thing.

Those lyrics were strongly suggested the listener to never give up hoping and dreaming. Furthermore, it also implies that love from the loved ones would be able to drive out fears and feel free to begin the new life.

\section{"When you look at me I can touch the sky \\ I know that I'm alive"}

(Stanza 3)

The bold expression in stanza 1 line 1-2 expressing metaphorical expression that representing the feeling of author, that extremely happy somehow she could touch the sky.Touching the sky clearly representing the feeling of being in the highest states of happiness and highest pleasure of experiencing such a miraculous moment, whereas Celine just has a new born baby as the reason of the feeling of happiness.

"You've set my heart on

fire

Filled me with love

Made me a woman on clouds above" (Stanza 4)

The bold expression in stanza 4 line 1 presenting a courage or spirit that 
emphasized by word "fire". Here, the author tried to express her feeling of enthusiastic of the new life she carries from now on. Another expression of honored reflected in the stanza 4 line 3, whereas she felt highly honored that being represented by "a woman on clouds". It was clearly pictured the position of a woman that being appreciated with high honor after having a baby.

\section{Symbols in the Form of Personification}

The hope in thissong lyric viewed as a strengthened point that tells the listener that Celine is extremely happy that time. It implies strong encouragement inside that makes her really excited about life she is living. This powerful courage revives the spirit to face life challenges and obstacles forward. As can be seen in the following quotations:

I couldn't get much higher

My spirit takes flight

Cause I'm alive (Stanza

The author used personification which is giving the qualities of living ones to the abstract object or non-living ones that identified as "my spirit" that takes flight. Imagine how a spirit that does not even has a form taking a flight. It wassimply used to characterize the powerful encouragement by hope within Celine's soul that pictured as a human being that flies high when she feels extremely happy and ready for life challenge forward. This quotes bring a strong message for always be grateful and keep cheerful in facing whatever life might bring ahead. It seems that it is an affirmation of the fourth stanza which the spirit of having a child is likely filled with love, an uncontrolled feeling of Celine.

The use of personification by the author himself is to picture the power of hope that may drive someone to feel safe and seeing everything positively and eagerly. It can be concluded by analyzing the word used that perfectly suit to describe something within Celine is likely going outside and taking a flight higher and higher that is "the spirit" that shows as another human that get out of her body and fly high. It conveyed the unexplainable feeling of happiness that she experienced.

Another presentation of hope was also clearly conveyed in the following quotes. It shows a strong feeling in hope and courage to live ahead.

When you blessed the day

I just drift away

All my worries die

(Stanza 10)

The used of the word "worries" that is a non-living object to have qualities of the living ones that able to die. Imagine that "worries" as an abstract form that showing human emotion which is abstract to die. Of course it is so impossible to happen, though so the writer tries to tell the listener/reader that when we believe in ourselves, we can feel free from all the worries that push us down. This is telling us the ideas by the author reveals the message of hope that altogether encourage the listener to never giving up onto something we face in life. 
The strong connection between hope and courage were really implied by the author through a quotation that uses personification. He seems trying to deliver the message of how the feeling of someone that has faith everything will work well to encourage the listeners to live with positive thought and free from all worries that push us down in any circumstances.

The writer then found that through this song, the message was strongly declared by using various symbols to present hope. As in each stanza has revealed that first stanza is presenting the happy feeling, that Celine wants to convey to the world through her song that she is alive again with a presence of a child in her life, and it shows a feeling which it is not restrained anymore. The message of hope in the second stanza is having a something new in life changes everything. A new child is like the beginning of all things, wonder and hope. Therefore when a wife become a mother, it feels like we get wings to fly and feel alive.

The message of hope in the third stanza is an affirmation of the second stanza which the presence of a child can make a change. Especially when you and the child can feel the same feeling each other, or when the child can touch us as a mother for the first time, it feels like we can touch all the sky and want to fly.

The message of hope in the fourth stanza is the presence of a child can set our life too, it means life changes when we have a child or when we have our own family, it's like a reason to smile, laugh and it gives us a whole other perspective on why we wake up everyday. Moreover we become more careful about what we do, and we can learn many things and make us as a real woman.

The message of hope in the fifth stanza is an affirmation of the fourth stanza which the spirit of having a child is like we filled with love, an uncontrolled feeling of Celine.

The message of hope in the seventh stanza is having a child for the first time is there are so much joyful, rising spirits high, truly an unexplainable happiness that can never be equaled by anything in the world.

The message of hope in the eighth stanza is being a mother is such a great responsibility that needs a lot of sacrifices but on the other hand is also a very rewarding experience. Therefore the lyrics in the eighth stanza give a message as a mother we have to be the one who is standing beside the child, even have to through hard and good times.

\section{Conclusion}

The symbolism of hope in the song was clearly presented in the form of figurative language that are metaphor and personification. The reason why using figurative language itself is to make listener able to feel the invisible and sensuous representation of hope that experienced by Celine in that two chosen songs.It is also revealed the strong encouragement, positivity and motivation to make people get their hope back just by listening to the song.It seemed that by listening to the songs, the listener may gain something inside their self that push them to keep optimist, 
excited and confident to face every challenges forward in life.

Apart from it, vocabulary components the teacher should take account of several criteria. Since, song has those criteria which are: authentic, have various new vocabulary, flexibly match, delivering cultural aspect, and fun to be learned.

Therefore, the writer concluded that Celine Dion'ssongs "A New Day Has Come and I'm Alive in Album A New Day Has Come" have symbols that presented hope in forms of metaphors and personifications which may drive the listener to believe in heart that by keeping the hope inside, the happiness will always stay.Hereby, the writer found that through the song that motivated someone, teacher may also use those and other motivational songs to build self-confidence and enhance vocabulary.

\section{Suggestion}

Literary work is like everything seen in life. It is very interesting lesson and important to us as a student or a learner to read. This study also focused on the values which can be obtained in the lyrics of Celine Dion's songs in album "A New Day Has Come". It is containing moral views of hope in normal human life in general.

There are some suggestions that can be the important point for us in life. We once lost hope in life, and it was a period in life that we would never want to take back. Actually it helped us to realize just how much those situations build a rock solid foundation ahead. Just remember that we are not alone in the loss of hope. There are many of us lose hope from time to time, and when we are pushing towads a goal, we seemingly will feel lose all hopes for a while. But remember hope is defined as the expectation of good things to come, only belief, efforts and our patience that can bring us to good things we want.

\section{REFERENCES}

Alonso, H. R.Yip Harburg: Legendary Lyricist and Human Rights Activist. Wesleyan University Press Middletown, Connecticut. 2012

Bogdan, Robert and Sari Biklen. Qualitative Research for Education ; An Introduction to Theory and Methods 2nd edition. Boston Aliyn and Bacon Inc.1982.

Brandon J. Elements of Song. USA. Mon, Aug 11, 01:34 PM. 2014

Retrievedfrom: $<$ http://www.son gwriting.net/blog/bid/207465/So ngwriting-Tips-10-Elements-ofa-Song>

Danbury, Conn. Encyclopedia of Americana. N. P. : Grolier Incorporated. 1998.

Delgado, Melvin. Music, Song, Dance, And Theater. Oxford University Press.

Davis, Sheila. The Craft Of Lyric Writing. United States Of America. 1985.

Griffee, Dale T. Songs In Action. UK. Phoenix ELT

Griffith, Kelly. Writing Essays about Literature. Washington : Harcourt Brace Javanovich Publisher, 1998

Hatch, Evelyn Marcussen - Brown, Cheryl. Vocabulary, Semantics, and Language Education. 
Cambridge: Cambridge

University Press. 1995.

Hebert, George, Germain. Celine: The

Authorized Biography of Celine

Dion. Dundurn Press, 1986.

Hudson, W Henry. An Introduction to the Study of Literature. Atlantic New Delhi publisher and Distributors(P) Ltd. 1998, 2006

Jolly, Y. S. The Use of Songs in Teaching Foreign Languages. The Modern

Language Journal, 59 (1/2), 11-14. 1975.

$\leq \underline{\text { http://dx.doi.org.10.2307/3254 }}$

$\underline{40>}$

Juslin, P.N., and Laukka, P.

Communication of emotions in the vocal expression and music

performance :Different channels,

same code? Psychological Bulletin.

$\underline{2005}$

Kroodsma, Donald E., and Edward H. Miller. Acoustic Communication in Birds. Volume 2 Song Learning and its Consequences. New York London, Academic Press, INC.1942.

Maru, Mister G. Reconciling Literary Text with Learners' Trust in

EFL Class1. Paper Online. 56th TEFLIN International Conference on December 8- 10, in UIN Malang, Indonesia.2009

https://s3.amazonaws.com/acade mia.edu.documents/33072121/R econciling_Literary_Text_with_ Learners_TEFLIN_International _2009_UIN_Malang_Indonesia. pdf?

Maru, Mister G. Experimenting

Jeremiadic Approach as an
Alternative for TEFL in Meeting

the Demand of the 2013

Curriculum . Proceeding. 61th

TEFLIN International

Conference. Solo: Universitas

Negeri Solo.2014

http://scholar.google.co.id/citati ons?user $=\mathrm{gMI} 3 \mathrm{hzEAAAAJ} \& \mathrm{hl}=\mathrm{id} \# \mathrm{~d}=\mathrm{g}$ $\underline{\mathrm{S}}$

md cita- $d \& p=\& u=\%$ Fcitations

Maru, Mister G. Featuring an Ideal Woman in Ibsen's Ghost.

Basastra Journal. Lembaga Penelitian Unima: Universitas Negeri Manado. 99-108.2014

Marhamah, Rowiatun. A. Interpersonal Meaning Analysis Of Muse Song LyricsIn Black Holes And Revelation' Album. Yogyakarta State University, 2014.

Meyer M, Abrams. The Mirror and the Lamp. N. P : Oxford University, 1956.

Meyer M, Abrams. A Glossary of Literary Terms. Printed in the United States of America. 1971

Murphey, T. Music and Song. Oxford, England : Oxford University Press. 1992.

Perrine, Lawrence. Sound and Sense an Introduction to Poetry. New York : Brace and World, 1978.

Pettingill OS. Ornithology. Burgess, Minneapolis. 1970

Pradopo, Rachmat. Beberapa Teori Sastra, Metode Kritik, dan Penerapannya. Yogyakarta : Pustaka Pelajar, 1995.

Pamaruntuan, Pretty A. Love In The Lyric Of The Beatles In Album A Hard Day's Night. 2014 
Richards, J.Songs in Language Learning. TESOL Quarterly, 3(2), 161174, 1969.

Salcedo, Claudia. S. The Effects of Songs in The Foreign Language Classroom On Text Recall and Involuntary Mental Rehearsal. B. A. Lousiana State University (1982), M. A, Lousiana State University (1990)

Strickland, Jeffrey. Quantum Hope. Lulu Press Inc 2015

Stegger M, Lindsay G O, Antonelle D F and Jonathan P. The Wiley Blackwell Handbook of the Psychology of Positivity and Strengths. 2009

Sutton, Robert, Music Master ;The Elements Of The Theory Of Music. Training College Center, 1867.

Waluyo J. H. Teori dan pengajaran.

Wellek, Rene., and Austin Warren. Theory of Literature. New York : Harcourt Brace and Company, 1977.

Wilkins,David. A.Linguistics in Language Teaching. London: Edward

Arnold.1972. 